Canadian

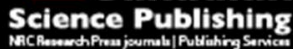

Canadian Geotechnical Journal Revue canadienne de géotechnique

\title{
Biogrouting Coarse Materials Using Soil-Lift Treatment Strategy
}

\begin{tabular}{|r|l|}
\hline Journal: & Canadian Geotechnical Journal \\
\hline Manuscript ID & cgj-2016-0167.R1 \\
\hline Manuscript Type: & Note \\
\hline Date Submitted by the Author: & 22-Jul-2016 \\
\hline Complete List of Authors: & $\begin{array}{l}\text { Mahawish, Aamir; Monash University } \\
\text { Bouazza, Abdelmalek; Monash University, } \\
\text { Gates, Will; Monash University, Civil Engineering }\end{array}$ \\
\hline Keyword: & biogrouting, coarse sand, ground improvement \\
\hline
\end{tabular}

SCHOLARONE ${ }^{m}$

Manuscripts 


\section{Biogrouting Coarse Materials Using Soil-Lift Treatment Strategy}

\section{Aamir Mahawish ${ }^{1}$, Abdelmalek Bouazza ${ }^{2}$, Will P. Gates ${ }^{3}$}

${ }^{1}$ PhD Student, Department of Civil Engineering, 18 Alliance Lane, Monash University, Vic. 3800, Australia, phone: +61 3 99058901, Fax: +61 399054944.

email:aamir.mahawish@monash.edu

${ }^{2 *}$ Professor, Department of Civil Engineering, 23 College Walk, Monash University, Vic. 3800, Australia, phone: +61 39905 4956, Fax: +61 399054944 email:malek.bouazza@monash.edu

${ }^{3}$ Senior Research Fellow, Australian Centre for Infrastructure Durability, Institute for Frontier Materials, Deakin University, Burwood, Vic 3125, Australia., phone +61 35224 2117; email:will.gates@deakin.edu.au (formerly Monash University) 
Abstract: This paper investigates the feasibility of using a soil-lift bio-grouting treatment strategy to improve the mechanical properties of coarse sand with the view of applying it to stone columns/sand piles and rammed earth columns type of applications. A two-phase percolation approach was adopted in this study that included percolating a bacterial suspension Sporosarcina Pasteurii in the first phase and a cementation solution in the second phase. This process was repeated every two treatments. The study reveals that an increase in the number of soil-lifts negatively influenced the mechanical properties of the bio-cemented coarse sand. However, the minimum strength and stiffness achieved $(2.8 \mathrm{MPa})$ in this study was sufficient to mitigate slumping of a soil column that may occur during installation or excessive radial expansion. Furthermore, it is shown that a single lift treatment can lead to a very high increase in strength and stiffness (up to 8.9 $\mathrm{MPa}$ and 2.3 GPa, respectively). However, calcite distributions within bio-cemented soil columns piles were quite heterogeneous with increasing number of soil lift treatments. Soil-lift treatment can be seen as a practical strategy that can be used to inject treatment liquids in deeper depths, such as in soil columns piles.

Keywords: Biogrout, coarse sand, microbial induced calcite precipitation 


\section{INTRODUCTION}

The ground can be improved by many different techniques including densification through blasting, vibration and compaction, pre-compression, addition of admixtures including lime and cement, installation of stiffening columns and several other methods (Mitchell 1981; Mitchell and Jardine 2002; Karol 2003; Gniel and Bouazza 2009; 2010; Chu et al. 2013). Recently, biologically mediated processes have been used for ground improvement to mitigate liquefaction, erosion, and improve hydraulic and strength properties of granular soils (Bouazza et al. 2009; Stabnikov et al. 2011). In particular, microbial induced calcite precipitation (MICP) by urea hydrolysis has been shown to be a viable ground improvement alternative which can mitigate soil liquefaction potential, stabilize coastal sand dunes and slopes, suppress dust, increase bearing capacity of foundations and strengthen soft marine clays (DeJong et al. 2006; Whiffin et al. 2007; Bang et al. 2009; DeJong et al. 2010; Chou et al. 2011; Mortensen and DeJong 2011; Paassen 2011; Yasuhara et al. 2011; Chu et al. 2012; Montoya 2012; Rong et al. 2012; Al Qabany and Soga 2013; Cheng et al. 2013; Soon et al. 2013; Ivanov et al. 2015; Lin et al. 2016).

Ureolysis-driven MICP relies mainly on urease-producing bacterial strains such as Sporosarcina pasteurii. MICP occurs by adding urease-producing bacteria into a soil matrix to promote catalysis of urea hydrolysis as described by the following equations (Hammes and Verstraete 2002):

$$
\begin{array}{ll}
\mathrm{CO}\left(\mathrm{NH}_{2}\right)_{2}+\mathrm{H}_{2} \mathrm{O} \underset{\text { Urease Enzyme }}{\longrightarrow} \mathrm{CO}_{2}+2 \mathrm{NH}_{3} & \mathrm{pH} \uparrow \\
2 \mathrm{NH}_{3}+\mathrm{CO}_{2}+\mathrm{H}_{2} \mathrm{O} \longrightarrow 2 \mathrm{NH}_{4}{ }^{+}+\mathrm{CO}_{3}{ }^{2-} &
\end{array}
$$


As can be seen in equation 2, urea hydrolysis produces an excess of dissolved carbonate ion. In the presence of excess calcium ions, calcium carbonate is precipitated spontaneously by the reaction given in Eq. (3)

$$
\mathrm{Ca}+\mathrm{CO}_{3}{ }^{2-} \longrightarrow \mathrm{CaCO}_{3} \longrightarrow \mathrm{pH} \downarrow
$$

Deposited calcite on the immobilised bacterial cell surfaces creates cementitious bridges between loose soil particles leading to soil solidification and increase in strength and stiffness (Whiffin et al. 2007; DeJong et al. 2010; van Paassen et al. 2010; Mortensen et al. 2011; Chu et al. 2012; Al Qabany and Soga 2013).

This paper focuses on the possibility of using a bio-grouting process based on MICP to increase the stiffness and strength of coarse granular soils with the view of applying it to sand piles/stone columns or rammed columns commonly used to improve weak soil sites. The objective of this study is to show the feasibility of treating a coarse sand column using gravity-driven percolation process combined with soil-lift treatments strategy. Various soil-lift strategy $(1,2,3,4$, and 5 soil lifts) are undertaken to test its applicability to MICP- treated coarse sand columns. The effect of soil-lift strategy on dry unit weight, calcite precipitation content and strength and stiffness of biocemented coarse sand columns is discussed and analysed.

\section{MATERIALS AND METHODS}

\section{Bacterial suspension and cementation solution}

Urease producing bacteria used was Sporosarcina Pasteurii (ATCC@ 11859). A urea hydrolysing bacterium was grown at $30{ }^{\circ} \mathrm{C}$ in an ammonium-yeast extract medium $(20 \mathrm{~g} / \mathrm{L}$ yeast 
extract, $10 \mathrm{~g} / \mathrm{L}\left(\mathrm{NH}_{4}\right)_{2} \mathrm{SO}_{4}$ and $130 \mathrm{mM}$ tris buffer $(\mathrm{pH}=9.0)$. The individual recipes were autoclaved separately and then mixed together post sterilization. A group of 1 litre bottles containing a growth medium were inoculated with two-percent of Sporosarcina Pasteurii stock culture and incubated aerobically at $30{ }^{\circ} \mathrm{C}$ in a shaking water bath $(200 \mathrm{rpm})$. The bacterial cells were harvested at a final optical density $\left(\mathrm{OD}_{600}\right)$ of 3.0-3.5 using WPA $\mathrm{CO} 8000$ spectrophotometer (BioChrom Ltd), equivalent to $3.8 \times 10^{8}-4.7 \times 10^{8}$ cells $/ \mathrm{ml}$ based on equation 4 (Ramachandran et al. 2001).

Number of bacterial cells $=8.59 \times 10^{7} \times \mathrm{OD}_{600} 1.3627$

An enzyme urease activity of $21.45 \mathrm{mM} / \mathrm{min}$ was used in this study. The bacterial cells were harvested at the beginning of the stationary growth phase, in which the size of a population of bacteria remained relatively constant to ensure that no further growth of bacterial cells could occur in the granular columns during the prescribed retention time (incubation time). The reason for this was to ensure that same number of bacterial cells was used in each sand column due to the lack of required nutrient to grow more bacterial cells. The harvested microorganisms were stored at $4^{\circ} \mathrm{C}$ in the 1 litre bottles for a maximum of two weeks. Ureolytic process was driven by using urea-calcium chloride cementation solutions. The concentration of cementation solution recipes were $1 \mathrm{M}$ of urea and $1 \mathrm{M}$ of calcium chloride.

\section{Sand}

The sand used in this study has an average grain size of $1.6 \mathrm{~mm}$. It is classified as poorly graded coarse sand (SP) according to the Unified Soil Classification System (ASTM 2006). Maximum and minimum dry densities measurements were conducted in accordance with ASTM D4253 and 
ASTM D4254, to control compaction of the sand column model. Summary of the sand properties (specific gravity, Gs, coefficient of curvature, $\mathrm{Cc}$, coefficient of uniformity, $\mathrm{Cu}$, the medium grain size, $\mathrm{D}_{50}$, maximum and minimum void ratios, $\mathrm{e}_{\max }$ and $\mathrm{e}_{\mathrm{min}}$ ) are presented in Table 1 . The sand particles were typically sub-angular in shape and were deemed to be representative of the stone aggregate used for full scale stone columns (Gniel and Bouazza 2009, 2010).

\section{EXPERIMENTAL SET-UP AND TREATMENT METHODOLOGY}

Figure 1 shows a typical column used in the current study. It is made of a split mould Poly Vinyl Chloride (PVC) pipe, $220 \mathrm{~mm}$ high and with an internal diameter of $51 \mathrm{~mm}$ when assembled together. A wire mesh and filter paper were placed at the bottom of the column to minimise the loss of sand grains during preparation and treatment. The columns were positioned vertically with fully open top and control valve at the bottom. Soil placement was based on the use of various soil lifts and included the option of using 1, 2, 3, 4, and 5 lifts, respectively. Dry coarse sand was pluviated into the specimen mould in individual lifts. Each lift was compacted to a relative density of $60 \%$ due to their sub-angular particle shape and poor grading, using a vibratory compaction method. After placement of each soil lift, tap water was flushed through to expel air from the pore matrix.

A two-phase biochemical treatment protocol was adopted in this study and included sequential percolation of bacterial suspensions and cementation solutions from the top of the columns (Cheng 2012). The process was initiated by alternating percolation of a quarter pore volume $(20 \mathrm{ml})$ of bacterial suspension and a quarter pore volume $(20 \mathrm{ml})$ of cementation solution within the first lift in the case of one soil lift strategy. A 24-hour retention time was chosen to achieve better intermixing between bacteria and substrates. The second biochemical treatment included 
only $40 \mathrm{ml}$ of the cementation solution and the same aforementioned retention time was used. The previous processes were considered as two biochemical treatments and repeated up to 16time, which was equivalent to 32-biochemical treatment. For instance, a three-soil lift was was achieved by dividing the total specimen length $(102 \mathrm{~mm})$ by three resulting in a lift thickness of $\sim 33 \mathrm{~mm}$. Five biochemical treatments for each lift was considered to obtain a reasonable improvement of the coarse sand. Once the first soil lift was emplaced it received 5- biochemical treatments based on the determined pore volume of the soil lift. The second lift received also 5 biochemical treatments, but this also means that lift 1 received an additional 5 biochemical treatments. This process was repeated until the final lift (lift 3), which itself received 22 biochemical treatments, resulting in the number of biochemical treatments (referred as NOT) shown in Figure 2 for each lift. A similar protocol was adopted for the other soil-lift columns. After completing the biochemical treatments of the soil lifts, the soil columns were percolated with deionized water to remove any residual chemicals from the pore throat of the coarse sand. The split mould was removed after 24 hours, and then the bio-cemented coarse sand columns were left to cure at a $30{ }^{\circ} \mathrm{C}$ temperature for two weeks to accelerate the bio-cementation process and obtain acceptable samples within a reasonable timeframe for experimental works. All the mechanical tests reported in this paper were conducted in a controlled room temperature $(20 \pm 2$ $\left.{ }^{\circ} \mathrm{C}\right)$. The samples for UCS test were then taken out their split moulds and the absences of the flat surfaces were overcome by using sulphur capping to obtain plane surfaces within $0.05 \mathrm{~mm}$.

\section{Unconfined Compressive Strength (UCS) Tests}

After completion of the biochemical treatments and curing periods, the bio-cemented coarse sand columns were subjected to UCS test to quantify any possible increase in strength and stiffness. An Instron 4204-50kN constant-displacement mode UCS machine and laser extensometer were 
used to conduct the UCS tests. All the tests were carried out at a constant rate of $1 \% / \mathrm{min}$ to monitor the propagation and observation of the shear failure in the samples. Calcite precipitation was quantified after completion of the UCS tests.

\section{Calcite content}

Gravimetric hydrochloric acid (HCL) washing technique was used to measure the amount of calcite precipitation in each column. Sub-specimens were collected from parts (top, middle and bottom) of the biocemented specimens after completion of the UCS tests. They were dried in an oven at $105{ }^{\circ} \mathrm{C}$ for 24 hours and then their masses were measured. Next, the specimens were rinsed with $2 \mathrm{M} \mathrm{HCl}$ to dissolve precipitated calcite and flushed with deionised water to allow the dissolved salts to be rinsed out from the specimens which then were left to dry for 24 hours. The difference between mass before and after acid wash was taken as the mass of calcium carbonate. The percentage of calcium carbonate was obtained by dividing the mass of calcium carbonate by the mass of coarse sand specimen.

\section{RESULTS AND DISCUSSION}

\section{Influence of soil-lift treatment strategy on calcite content of biocemented coarse sand}

Figure 3, shows the relationship between the amount of calcite precipitation in three regions (top, middle and bottom) of the bio-cemented coarse sand columns against the number of soil lifts. Even though the coarse samples were similarly treated in terms of number of biochemical treatments (e.g. up to 32-treatments), they show a variation in the amount and distribution of calcite precipitation. A visual investigation of these specimens was conducted and calcium carbonate was observed as a white deposition on the external surfaces of the coarse sand columns (see Fig.2). Calcite precipitation was more abundant toward the bottom portions in all 
specimens with the exception of the one-soil lift specimen, indicating that treating soil lifts technique resulted in a more heterogeneous distribution of calcite within the pore throat of the coarse sand. This is because the number of treatments was less in the upper compared to the lower parts of the soil (i.e.an increase in number of soil lifts resulted in less number of treatments for soil lifts near to the surface of the specimens)

It can be clearly seen from Figure 3 that calcite at the bottom of the (3-5) soil lift specimens was significantly higher than in the top part of these specimens and was twice the precipitated calcite content in the upper part of the five-lift soil column. Calcite precipitation content was in the range of approximately $21-22 \%$ per weight of dry coarse sand. In addition, Calcite precipitated mostly near the percolation point in the case of the one-soil lift due to the repeat of the percolation process which resulted in the adherence of the bacterial cells to the solid surfaces located near the percolation points. Utilizing one soil lift column with high calcium chloride concentration can lead to increase in ionic charges, and tend to promote bacterial adhesion (Faibish et al. 1998; Foppen and Schijven 2006) due to bacterial cells having a high negative zeta potential that are attracted to soil's particles under physical infiltrations (Dick et al. 2006). The average weight of calcite precipitation was $71.60 \mathrm{~g}, 71.00 \mathrm{~g}, 70.90 \mathrm{~g}, 68.20 \mathrm{~g}$ and $68.00 \mathrm{~g}$, respectively in specimens which have undergone one-lift, two-lift, three-lift, four-lift and five lift treatments. The efficiency of soil-lift columns strategy with regards to the amount of calcium used varied between $45 \%$ and $47 \%$ depending on the lift strategy used. 


\section{Effect of soil-lift treatment strategy on strength and stiffness of biocemented coarse sand}

Figure 4, shows the effects of soil-lift treatment strategy on the compressive strength and stiffness of specimens treated by the MICP method. The experimental results indicate that an increase of soil lifts negatively affected the strength and stiffness of bio-cemented coarse sand samples. It seems that the interaction between soil lifts resulted in the creation of regions with weak resistance, which eventually led to weaker specimens. Shear failures were observed to originate from the interface between the lifts (see figure 5), and were primarily dependent on the calcite-calcite contacts as it was observed that a thin layer of calcium carbonate resided onto surfaces of the soil particles (DeJong et al. 2010). Also, the calcite deposited was relatively weaker than the coarse sand particles due to the heterogeneous distribution of the calcite. Furthermore, because each lift was vibrated in place, this process might have also resulted in a capillary break which in turn could have affected how the treatment solutions penetrated between lifts. Notwithstanding the above, it can be seen from Fig. 4 that the strength and stiffness of biocemented coarse sand were improved despite the fact that strength and stiffness decreased as the number of lifts increased. The one soil lift treatment technique achieved the highest strength and stiffness (8.8 MPa and 2.27 GPa, respectively).

\section{Effect of soil-lift treatment strategy on dry density of coarse sand bound by microbial activities}

Figure 6, illustrates variations of the unconfined compressive strength and stiffness with dry unit weight. Strength increased with an increase in dry unit weight and a similar trend was observed for stiffness of bio-cemented coarse sand samples. A maximum strength and stiffness was achieved when the dry unit weight was approximately $19 \mathrm{kN} / \mathrm{m}^{3}$. This behaviour is well known in the case of using artificially cemented soils as the strength increases with an increase of 
cement content and unit weight. By contrast, van Paassen et al. (2010) stated that high variances were observed in the correlations of dry unit weight with strength and stiffness. They reported that part of these variances were due to differences in the initial dry unit weight (van Paassen et al. 2009). The core samples that were taken from a large-scale $\left(100 \mathrm{~m}^{3}\right)$ experiment were tested by conducting UCS and showed peak strength varying significantly from 0.7-12.4 MPa (van Paassen et al. 2010). The current study showed that a considerably high strength and stiffness using MICP-treated coarse sand can be achieved under various number of soil-lift treatment strategies. It is worth noting that dry unit weight increased with decreasing soil-lift number due to some deposited calcite flushing out of the columns. This is due to the vibratory compaction process adopted in this study to achieve the target relative density. Vibratory compaction has led to breakage of the bonds between particles and some of calcite crystals were consequently flushed out when applying treatments to the subsequent lifts.

\section{CONCLUSIONS}

MICP method faces many challenges in geotechnical application especially when it is considered as a potential enhancement to engineering properties of deeper soils when stone columns/sand piles or rammed columns are used. Although, bacterial suspension and cementation solution used in the MICP method have a low viscosity, the main practical difficulty resides on how to inject these solutions to the places where improvement is needed. To overcome these complexities, this study experimented utilizing various number of soil lifts. The study reveals that an increase of soil-lift number has a negative influence of the mechanical properties of the bio-cemented coarse sand. However, the improvement obtained was substantially greater than reported in other published studies in which soils with an average grain size less than $1 \mathrm{~mm}$ were used. The minimum strength and stiffness achieved in this study is enough to mitigate slumping of a soil 
column that may occur during installation or excessive radial expansion during loading and improve rammed columns capacity. Based on the findings from this study, the following conclusion can be drawn

1. Single soil lift column gave more homogenous calcite distribution than multiple soil lifts columns.

2. The main weaknesses in the multiple soil lifts columns were associated with interface between soil lifts.

3. Multiple soil lifts columns resulted in good strength and stiffness improvements in coarse sands and the maximum strength and stiffness was achieved by using one soil lift.

4. Strength and stiffness was dependent on the overall mass of the bio-cemented materials.

\section{REFERENCES}

Al Qabany, A. and Soga, K. 2013. Effect of chemical treatment used in MICP on engineering properties of cemented soils. Geotechnique 63 (4): 331-339

ASTM 2006. American Society for Testing and Materials. Standard Practice for Classification of Soils for Engineering Purposes (Unified Soil Classification System). West Conshohocken, Pa, ASTM Standard D2487.

Bang, S.S., Bang, S., Frutiger, S., Nehl, L.M., and Comes, B.L. 2009. Application of novel biological technique in dust suppression. Transportation Research Board $88^{\text {th }}$ Annual Meeting (No. 09-0831).

Bouazza, A., Gates, W.P., and Ranjith, P.G. 2009. Hydraulic conductivity of biopolymer-treated silty sand. Geotechnique, 59 (1):71-72.

Cheng, L., Cord-Ruwisch R., and Shahin, M. A. 2013. Cementation of sand soil by microbially induced calcite precipitation at various degrees of saturation. Canadian Geotechnical Journal 50(1): 81-90. 
Chou, J.C. 2012. Liquefaction Mitigation Using Microbial Induced Calcite Precipitation. GeoCongress 2012, State of the Art and Practice in Geotechnical Engineering, pp. 1918-1927.

Chou, C. W., Seagren, E. A., Aydilek, A. H., and Lai, M. 2011. Biocalcification of Sand through Ureolysis. Journal of Geotechnical and Geoenvironmental Engineering 137(12): 1179-1189.

Chu, J., Ivanov, V., Naeimi, M., Stabnikov, V. and Liu, H. L. 2013. Optimization of calciumbased bioclogging and biocementation of sand. Acta Geotechnica 9(2): 277-285.

Chu, J., Stabnikov, V., and Ivanov, V. 2012. Microbially induced calcium carbonate precipitation on surface or in the bulk of soil. Geomicrobiology Journal 29(6): 544-549.

DeJong, J. T., Fritzges, M. B., and Nüsslein, K. 2006. Microbially Induced Cementation to Control Sand Response to Undrained Shear."Journal of Geotechnical and Geoenvironmental Engineering 132(11): 1381-1392.

DeJong, J. T., Mortensen, B. M., Martinez, B. C., and Nelson, D. C. 2010. "Bio-mediated soil improvement." Ecological Engineering 36(2): 197-210.

Dick, J., De Windt, W., De Graef, B., Saveyn, H., Van der Meeren, P., De Belie, N., and Verstraete, W. 2006. Bio-deposition of a calcium carbonate layer on degraded limestone by Bacillus species. Biodegradation 17(4): 357-367.

Faibish, R. S., Elimelech, M., and Cohen, Y. 1998. Effect of interparticle electrostatic double layer interactions on permeate flux decline in crossflow membrane filtration of colloidal suspensions: an experimental investigation. Journal of colloid and interface science 204(1): 77 86.

Foppen, J., and Schijven, J. 2006. Evaluation of data from the literature on the transport and survival of Escherichia coli and thermotolerant coliforms in aquifers under saturated conditions. Water Research 40(3): 401-426.

Gniel, J., and Bouazza, A. 2009. Improvement of soft soils using geogrid encased stone columns. Geotextiles and Geomembranes 27(3): 167-175.

Gniel, J., and Bouazza, A. 2010. Construction of geogrid encased stone columns: A new proposal based on laboratory testing. Geotextiles and Geomembranes 28(1): 108-118. 
Hammes, F., and Verstraete, W. 2002. Key roles of pH and calcium metabolism in microbial carbonate precipitation. Reviews in Environmental Science and Biotechnology 1(1): 3-7.

Ivanov, V., Chu, J., Stabnikov, V., and Li, B. 2015. Strengthening of soft marine clay using bioencapsulation. Marine Georesources and Geotechnology 33(4): 320-324.

Karol, R. H. 2003. Chemical Grouting And Soil Stabilization. New York, M Dekker.

Lin, H., Suleiman, M. T., Jabbour, H., Brown, D., and Kavazanjian, E. Enhancing the axial compression response of pervious concrete ground improvement piles using bio-grouting. Journal of Geotechnical and Geoenvironmental Engineering (in press http://dx.doi.org/10.1061/(ASCE)GT.1943-5606.0001515)

Mitchell, J.K. 1981. Soil Improvement: state of the art report. Proc. 10th International Conference on Soil Mechanics and Foundation Engineering, Stockholm, Sweden. 4: 509-565.

Mitchell, J.M., and Jardine, F.M. 2002. A guide to ground treatment. CIRIA publication C573(London).

Montoya, B.M. 2012. Bio-mediated soil improvement and the effect of cementation on the behavior, improvement, and performance of sand. $\mathrm{PhD}$ thesis, University of California, Davis.

Mortensen, B., and DeJong. J. 2011. Strength and stiffness of MICP treated sand subjected to various stress paths. Geo-Frontiers 2011. Advances in Geotechnical Engineering, ASCE.

Mortensen, B.M., Haber, M.J., DeJong, J.T., Caslake, L.F., and Nelson, D.C. 2011. Effects of environmental factors on microbial induced calcium carbonate precipitation. Journal of applied microbiology 111(2): 338-349.

Paassen, L.A. v. 2011. Bio-mediated ground improvement: From laboratory experiment to pilot applications. Geo-Frontiers 2011:Advances in Geotechnical Engineering, pp. 4099-4108.

Ramachandran, S.K., Ramakrishnan, V., and Bang, S.S. 2001. Remediation of concrete using micro-organisms. American Concrete Institute Material 98(1): 3-9.

Rong, H., Qian, C.X., and Li, L.Z. 2012. Influence of molding process on mechanical properties of sandstone cemented by microbe cement. Construction and Building Materials 28(1): 238-243. 
Rong, H., Qian, C.X., and Li, L.Z. 2012. Study on microstructure and properties of sandstone cemented by microbe cement. Construction and Building Materials 36(0): 687-694.

Shanahan, C., and Montoya, B. 2014. Strengthening coastal sand dunes using microbial-induced calcite precipitation. Geo-Congress 2014: 1683-1692.

Soon, N.W., Lee, L.M., Khun, T.C., and Ling, H.S. 2013. Improvements in engineering properties of soils through microbial-induced calcite precipitation. KSCE Journal of Civil Engineering 17(4): 718-728.

Stabnikov, V., Naeimi, M., Ivanov, V., and Chu, J. 2011. Formation of water-impermeable crust on sand surface using biocement. Cement and Concrete Research 41(11): 1143-1149.

Van Paassen, L.A., Ghose, R., van der Linden, T.J., van der Star, W.R., and van Loosdrecht, M.C. 2010. Quantifying biomediated ground improvement by ureolysis: large-scale biogrout experiment. Journal of Geotechnical and Geoenvironmental Engineering 136(12): 1721-1728.

Van Paassen, L.A., van Loosdrecht, M.C.M., Pieron, M., Mulder, A., Ngan-Tillard, D.J.M., and Van der Linden, T.J.M. 2009. Strength and deformation of biologically cemented sandstone. ISRM Regional Symposium-EUROCK 2009, International Society for Rock Mechanics.

Whiffin, V.S., van Paassen, L.A., and Harkes, M.P. 2007. Microbial carbonate precipitation as a soil improvement technique. Geomicrobiology Journal 24(5): 417-423.

Yasuhara, H., Hayashi, K., and Okamura, M. 2011. Evolution in mechanical and hydraulic properties of calcite-cemented sand mediated by biocatalyst. Geo-Frontiers 2011:Advances in Geotechnical Engineering, pp. 3984-3992. 


\section{Figure Captions}

Fig. 1. Schematic setup of experimental columns.

Figure 2. Layout of MICP-treated coarse sand using various soil lifts strategy (* NOT refers to Number of Treatments): (a) treatment of one soil-lift; (b) treatment of two-soil lift; (c) treatment of three-soil lift; (d) treatment of four soil lift; (e) treatment of five-soil lift.

Figure 3. Effect of number of lift on the amount of calcite precipitation of bio-cemented coarse sand.

Figure 4. Effect of Number of soil layers on the strength and stiffness of bio-cemented coarse sand.

Figure 5. Shear failure propagation at the interface of three-soil lift column.

Figure 6. Effect of dry unit weight on the strength and stiffness of bio-cemented coarse sand. 


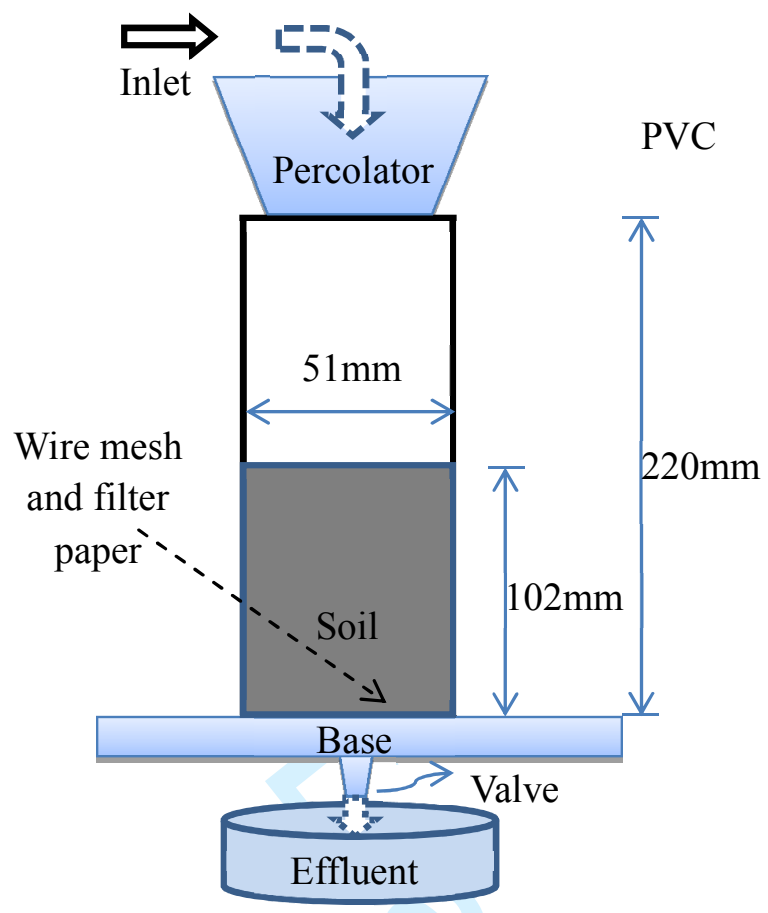

Fig. 1. Schematic setup of experimental columns. 
(a)

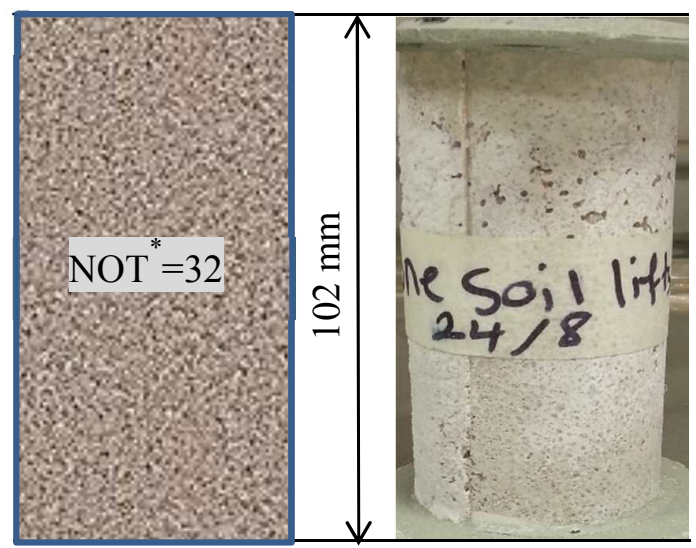

(c)

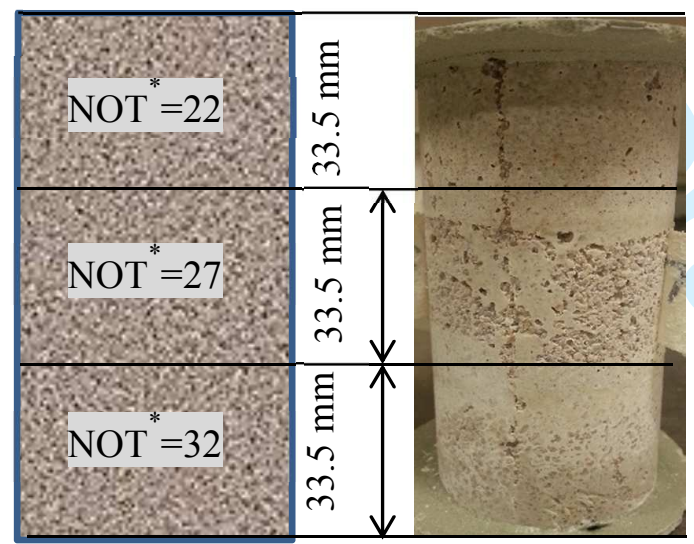

(b)

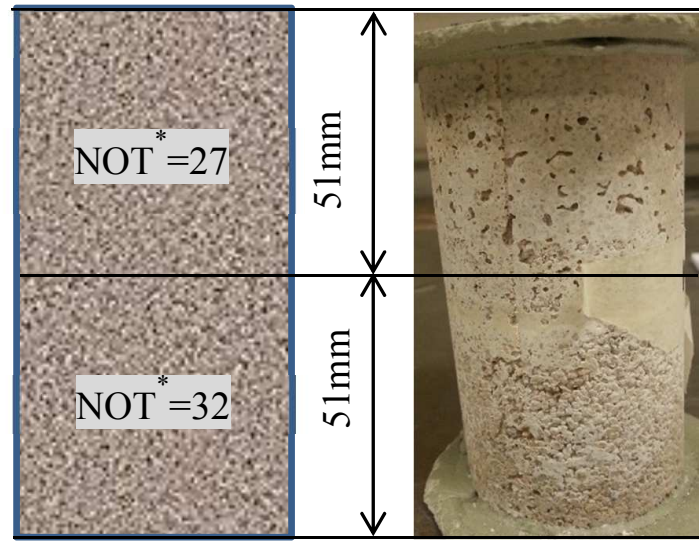

(d)

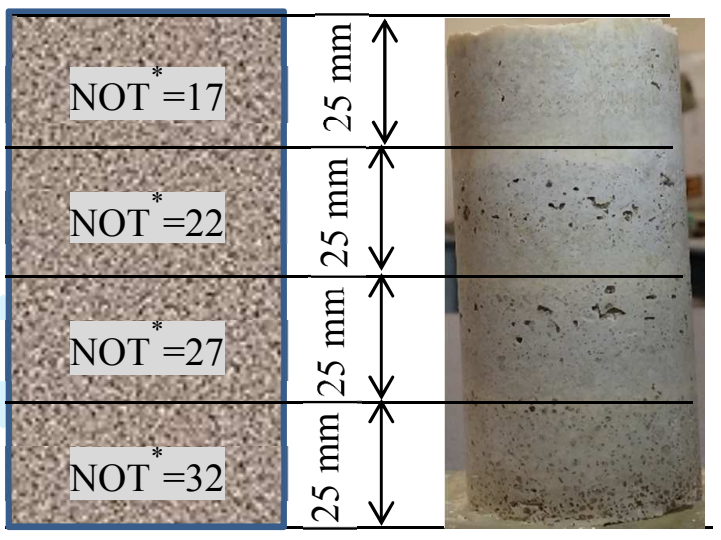

(e)

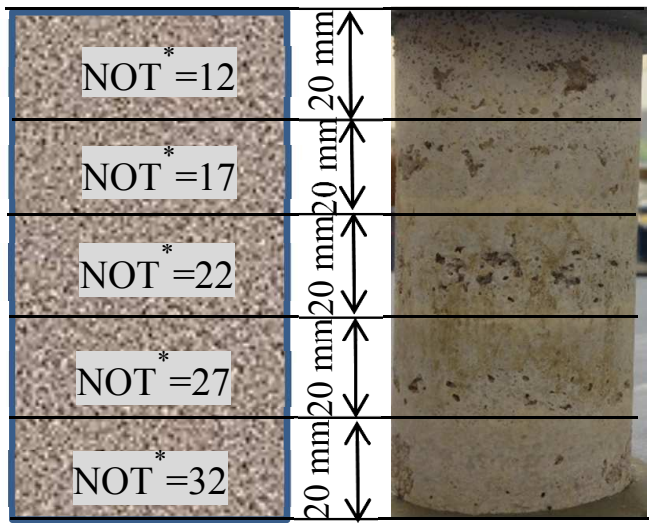

Figure 2. Layout of MICP-treated coarse sand using various soil lifts strategy (* NOT refers to Number of Treatments): (a) treatment of one soil-lift; (b) treatment of two-soil lift; (c) treatment of three-soil lift; (d) treatment of four soil lift; (e) treatment of five-soil lift. 


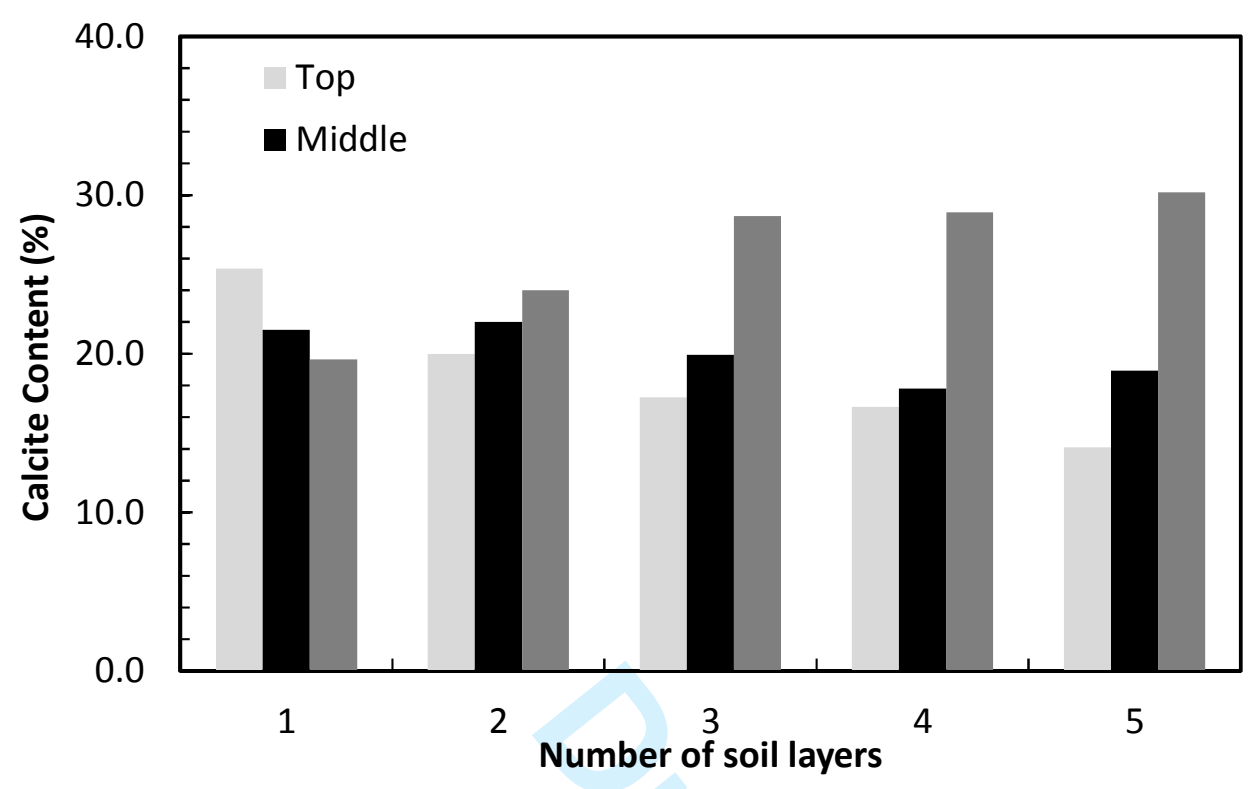

Figure 3. Effect of number of lift on the amount of calcite precipitation of bio-cemented coarse sand. 


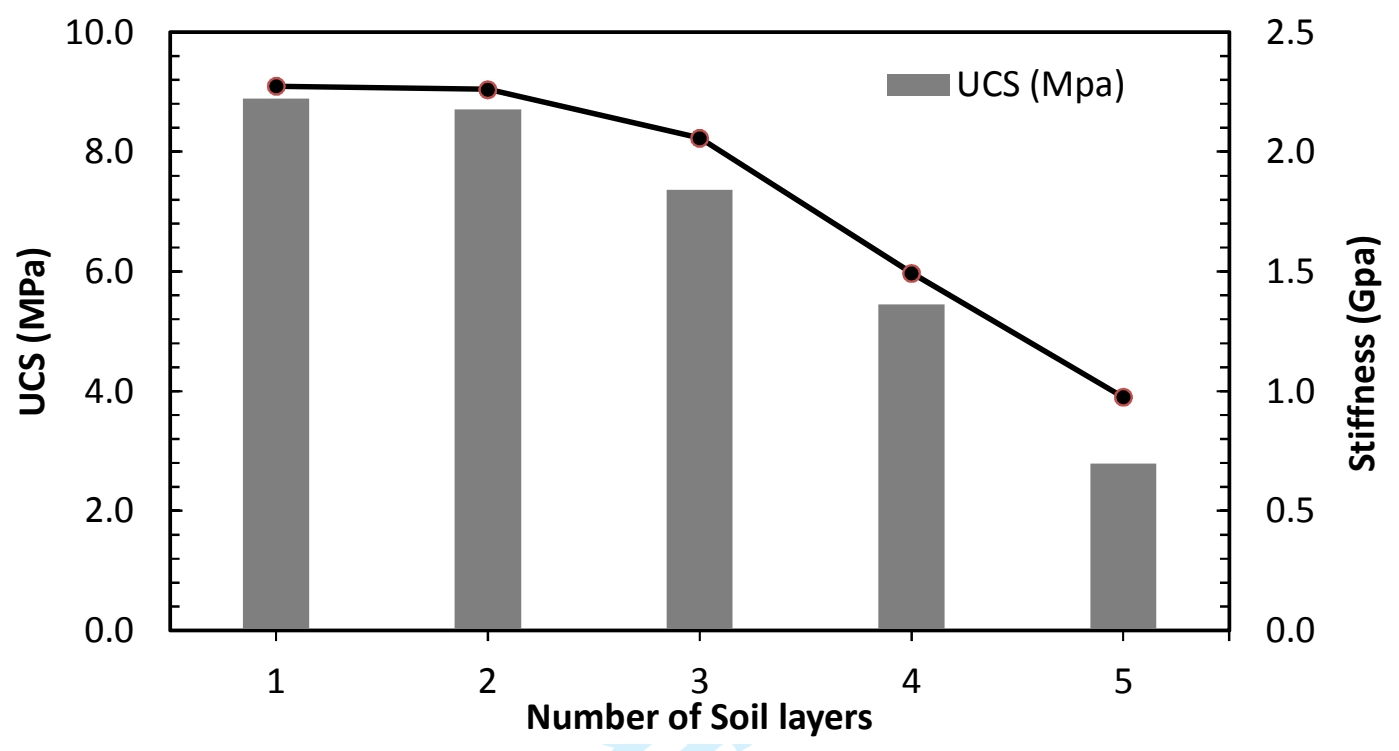

Figure 4. Effect of Number of soil layers on the strength and stiffness of bio-cemented coarse sand. 


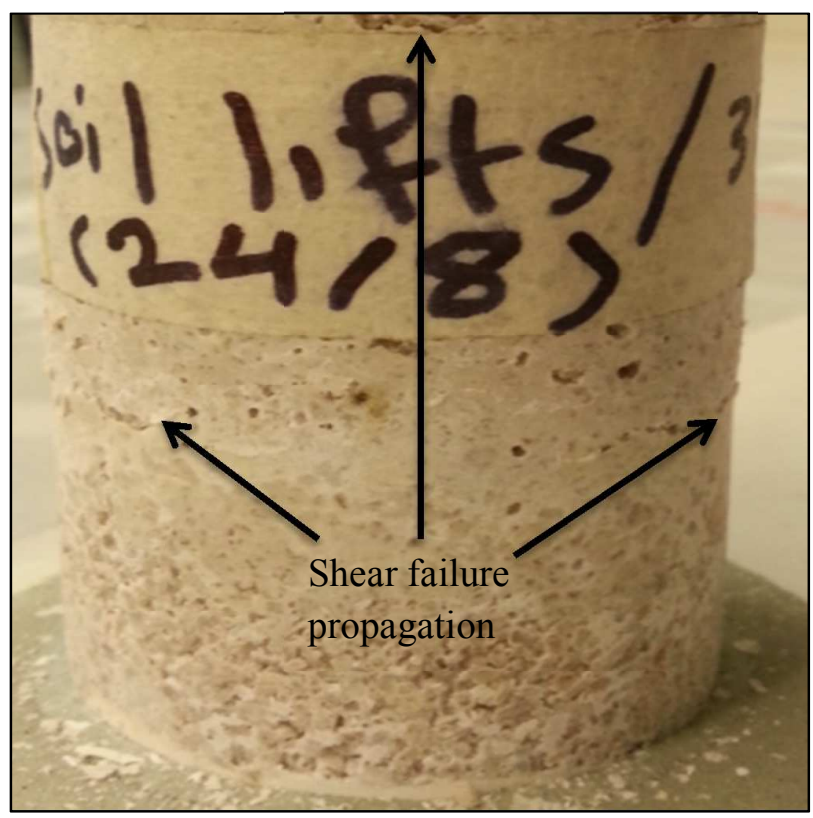

Figure 5. Shear failure propagation at the interface of three-soil lift column 


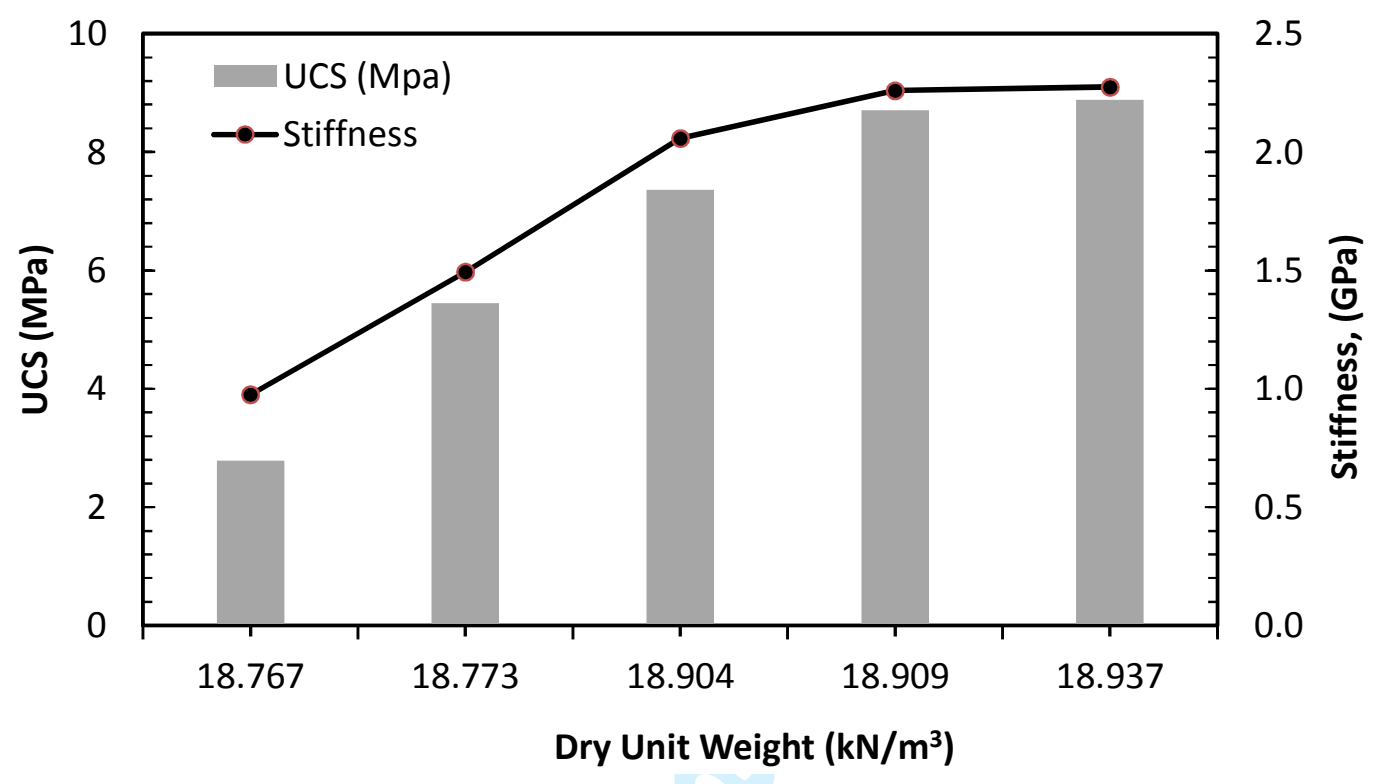

Figure 6. Effect of dry unit weight on the strength and stiffness of bio-cemented coarse sand. 
Table 1: Coarse sand characteristics

\begin{tabular}{|c|c|c|c|c|c|c|c|}
\hline Soil Type & Classification & $\mathrm{Gs}$ & $\mathrm{Cc}$ & $\mathrm{Cu}$ & $\begin{array}{c}\mathrm{D}_{50} \\
(\mathrm{~mm})\end{array}$ & $\mathrm{e}_{\max }$ & $\mathrm{e}_{\min }$ \\
\hline Grade 8/16 & $\mathrm{SP}$ & 2.64 & 0.97 & 1.35 & 1.60 & 0.84 & 0.55 \\
\hline
\end{tabular}

